\title{
A Study of Users and Non-Users of Internet Banking in Malaysia
}

\author{
Jayaraman Munusamy, Sanmugam Annamalah, and Shankar Chelliah
}

\begin{abstract}
This study aims to identify the perceptual differences between Internet Banking Adopters and Non-adopters especially in the Malaysian Retail Banking Sector. It investigates whether the perception varies between adopters and non-adopters on the adoption factors such as easier to operate, convenient to use, hassle free, reliable, safer to use and requirement for good Internet connections. This study employs a quantitative approach using a questionnaire survey at selected banks in Malaysia. The results indicate that there are significant differences in perception between internet banking adopters and non-adopters in terms of easier to operate, convenient, no hassle, reliable, safer to use and requirement for good Internet connections. Therefore, the result suggests managerial implications for retail bankers in Malaysia to minimize the risk perception of the internet banking among the non-adopters of the internet banking.
\end{abstract}

Index Terms-Internet banking, adopters, non-adopters, retail banking, perceptions.

\section{INTRODUCTION}

With the emergence of new digital technology, the banking industry has engaged information technology (IT) to acquire, to process and to deliver the information to banking customers. Customers are becoming value-sensitive and banks need to constantly innovate and update to match customers' expectation and to provide convenient, reliable, and expedient services. Driven by the competition among retail bankers, to capture a larger share of the banking market, banks have started introducing its distribution channel via a Internet.

In Malaysia, the electronic revolution commenced in the 1970's with the introduction of Automated Teller machine's (ATM) followed by telebanking in the 1990's and finally on 1st June 2000, Bank Negara has endorsed for locally owned commercial banks to offer Internet banking (BNM 2000). Malayan Banking Berhad (Maybank) became the first bank to offer Internet banking services on 15th June 2000. The services include banking enquiry functions, bill payment, credit card payment, fund transfer, account summary and transaction history. At present all domestic banks, which have been given the anchor bank status have their respective websites to perform Internet banking [1].

The Internet, as an enabling technology, has made banking products and services available to more customers and eliminated geographic and proprietary systems barriers [2]. The success of internet banking would greatly depend on the adoption rate of this technology by bank customers.

Manuscript received April 29, 2012; revised June 15, 2012.

J. Munusamy is with the Masterskill University College Education Group (e-mail: dr.jayaraman@limkokwing.edu.my).
Adoption of internet banking is driven by a range of various factors such as those described in the research framework by [3] on security, privacy and trust issues; [4] on characteristics of diffusion of innovation (e.g. relative advantage, complexity) and [5] on adoption of internet banking model comprising other factors such as demographics, consumer attitude, service quality and computer knowledge. Knowledge on the drivers of adoption of internet banking serves an advantage for banks because it facilitates the development of successful marketing strategies in order to capture a larger internet banking market share [6]. In addition, internet banking has led retail banks to improve effectiveness and efficiency of banking operations through reduction in transaction cost and increase in the speed of service [7].

\section{PRoBlem StATEMENT}

Intensity of Internet use in private households in Malaysia is on the increase as revealed by [8]. The survey determined that there were 2,473,000 household Internet users in the country as at 1 December 2006, out of which $23.6 \%$ of the usage if for financial activities (e-Banking). The survey indicated an increase of $9 \%$ as compared to the result recorded in Year 2005, 14.6\%. Despite the progress that has been achieved, Malaysians however, remain high users of currency notes and coins (BNM, 2005). The positive growth in the trend of online financial activities by retail consumers is lagging as compared to worldwide indicator and there is still room for improvement. Based on a survey that was carried out worldwide by [9], results indicated that one third of Brazilians and Portuguese (30\%) bank online daily, along with 28 percent of Poles and 27 percent of Chileans. In Asia, a significant number of Kiwis (25\%), Indians (20\%) and Hong Kongers (18\%) claimed to bank online every day, compared to a global average of 14 percent. Studies on Internet banking suggest that an internet-based consumer banking strategy may be effective, with reports of more profitable, loyal and committed consumers compared with traditional banking consumers [10] and [11]. In Malaysia, with the rapid technological advancements and increasing consumer demands for more efficient delivery services, the financial landscape has continued to transition towards the increased significance of Internet Banking as one of banking distribution channels (BNM, 2005).

The relative success of internet banking can be gauged by identifying the current and anticipated users of Internet. Table 1 summarizes the penetration rate of internet banking adopters from 2006 to 3Q 2009 (MCMC, 2009). In Malaysia, the internet banking adoption rate is $25.9 \%$ in 3Q 2009, which is considered low to a country which has high number of Internet subscribers. 
TABLE I: INTERNET BANKING SUBSCRIBERS

\begin{tabular}{|l|l|l|l|l|}
\hline As at end of period & 2006 & 2007 & 2008 & $3 \mathrm{Q} 09$ \\
\hline $\begin{array}{l}\text { No. of subscribers } \\
\text { (million) }\end{array}$ & 3.2 & 4.6 & 6.2 & 7.5 \\
\hline $\begin{array}{l}\text { Of which: Individual } \\
\text { subscribers }\end{array}$ & 3.2 & 4.5 & 6.1 & 7.3 \\
\hline $\begin{array}{l}\text { Penetration to population } \\
\text { (\%) }\end{array}$ & 11.9 & 16.6 & 21.8 & 25.9 \\
\hline $\begin{array}{l}\text { No of broadband } \\
\text { subscribers ('000) }\end{array}$ & 897 & 1,116 & 1,714 & 2,116 \\
\hline \\
Source: Central Bank of Malaysia and the Malaysian Communications and \\
Multimedia Commission (MCMC), 2009
\end{tabular}

Banking activities are easily digitised and automated and, thus, from an operational perspective, lend themselves to Internet [12, 13, 14, 15 and 16]. The potential competitive advantage of the Internet for banks lies in the areas of cost reduction and satisfaction of consumer needs [17] and [18]. In relation to costs, electronic transactions are a fraction of those conducted through the branch or even telephone [19]. The internet also offers banks the opportunity to better meet customer needs through enhanced interaction, data mining and customisation. Put together, the reduction of costs and increased customer satisfaction makes the logic of the Internet compelling [19]. The internet banking is a new type of information system that uses the innovative resources of the Internet and WWW to enable customers to effect financial activities in virtual space [20] and [21]. A study of US retail banking sector showed that the transaction costs of telephone banking are only 40 percent of those of providing the same service via physical branches [22].

In service industries in general and in the banking industry, in particular, the Internet has been explored and exploited as a means of improving service provision. Banks are not only competing in traditional banking services but also have expanded the scope of the competition to an e-environment with Internet banking services. These banks are introducing Internet banking as an assurance to their customers that they will be able to maintain a competitive quality service in future, in efforts to avoid losing their customers to other banks. Internet banking helps banks to build and maintain close relationships with their customers, reduces operating and fixed costs [23], and achieves more efficient and enhanced financial performance [24].

\section{A. Easier to Operate}

[25] found that Internet banking users had positive views on ease of use of the internet as compared to the non-users of Internet banking. They have highlighted the significant effect of computer self-efficacy on behavioural intention through perceived ease of use. From the customer perspective, the above research shows that the consumers benefit from internet banking in respect to ease of use. The Internet may also make it easier for the consumers to search and compare the offerings of different firms. This means the market will become more transparent, leading to increased price competition in businesses which offer easily comparable services and which are unable to build significant switching barriers or close relationships with the customers. Internet banking increases competition among banks, and allows banks to penetrate new markets and thus expand their geographical reach [26]. The increased number of Internet banking users will widen the reach of customers and the entry barriers in banking business will be reduced [27, 28, 29 and 30].

\section{B. Convenient to Use}

Internet banking is extremely beneficial to customers because of the savings in cost, time and space it offers, its quick response to complaints, and its delivery of improved services, all of which benefits make internet convenient to use [42 and 56]. The banking industry, as a service oriented business in particular, Internet has been discovered and deployed as means of improving service quality [20]. According to [23], the Internet offers a new way to distribute digitalizable services. A small firm will be able to interact with and sell its services to the whole world without having to maintain a global network of offices. Adopters of Internet banking perceive the service to be more convenient, less complex, more compatible and more suited to those who are tech savvy [19]. [31] survey suggested that the banks' operation management is the main factor affecting the success of automated teller machines (ATM's)

\section{Hassle Free}

Internet banking is extremely beneficial to customers because it is hassle fee in terms of cost, time, space it offers, response to complaints and other services [5, 32, 33, and 34]. Internet banking is hassle free and flexible. Because it gives benefits like no queuing in bank and consumers would be able to perform banking transaction anytime and anywhere. These hassle free benefits include efficient, speedy transfer of funds with lower transaction cost and also able to check transaction details regularly without any hassle [35 and 36].

\section{Reliable}

The significant effect of computer self-efficacy as highlighted by [22] on behavioural intention through perceived credibility. These banks are introducing Internet banking as an assurance to their customers that they will be able to maintain a competitive quality service in future, in efforts to avoid losing their customers to the branches of the foreign banks. The benefits attained by consumers from adopting internet banking in respect to transaction through enhanced control [12]. Early adopters of Internet banking seem to have more confidence that the system is more reliable [37 and 38]. As Internet banking transactions do no experience face-to-face interaction with bank staff, customers expect banks to provide valuable information through bank web sites as well as to provide prompt and reliable services [39]. [40] has developed a number of measures that can be used to measure Reliability in Internet banking services across five dimensions, namely, access, web site interface, trust, attention and credibility. Consumer trust is an important factor in practically all business-to-consumer interactions and a crucial aspect of 
electronic commerce [10].

\section{E. Safer to Use}

[25] found that Internet banking users had positive views on safer to use the internet as compared to the non-users of Internet banking. [22] highlighted the significant effect of computer self-efficacy on behavioural intention through perceived usefulness. [41] mentioned that the issue of security was found to be the most important factor that motivated Chinese consumer adoption of Internet banking. According to [12], Internet banking customers service quality, online information system quality, banking service product quality, overall internet banking service quality and customer satisfaction were found to be significant factors affecting adoption of internet banking. According to [42] consumers with Internet access from home, active interest in Financial Services, consumers having general online purchasing experience tend to find this Internet banking easy to use. [43] highlighted that customer private data management is a major concern in adoption of Internet banking. In addition, [44] expressed security and privacy of Internet banking transactions and confidentiality were found to be major factors affecting Internet banking adoption.

\section{F. Requirement for Good Internet Connections}

Motivation to use Internet banking has been intensified from slow and expensive dial up connections to faster and good quality connections which have been perceived to attracted new adopters of Internet banking [45]. The findings of the [4] indicate that the quality of the Internet connection and awareness is essential and has significant effects in the adoption of Internet banking. Few researchers also confirmed that speed of internet connections been an important element in Internet banking adoption [1 and 46]. Banking customers are always on the move due to job task and also family commitment which has made them mobile. Therefore, it is crucial for them to access a good and universal connection from any location worldwide and is universally accessible from any internet linked computer [17, 47, 38 and 48]. In addition mobility people are connected to Internet through broadband connections as it perceives to be providing good connection to perform Internet banking. This fact is supported by [49] that there will be an additional increase of 13.5 pp occurs if the individual has a broadband internet connection.

\section{HYPOTHESIS}

H1: As compared to non-adopters, adopters perceive Internet banking as Easier to Operate

H2: As compared to non-adopters, adopters perceive Internet banking as Convenient to Use

H3: As compared to non-adopters, adopters perceive Internet banking as Hassle Free

H4: As compared to non-adopters, adopters perceive Internet banking as Reliable

H5: As compared to non-adopters, adopters perceive Internet banking as Safer to Use

H6: As compared to non-adopters, adopters perceive Internet banking requires good Internet connections.

\section{SAMPLING}

This research adopted a convenient sampling to select respondents who were primarily the non adopters of Internet banking. These non adopters were selected randomly from branch banks in ten high density areas in Malaysia. The survey targeted a total of 300 individuals throughout Malaysia but the actual number of questionnaires collected represented 69 percent of the target sample size. The data was obtained through the use of structured questionnaires and the questionnaires were developed and pre-tested in Malaysia on individuals from various backgrounds. Information collected is to identify the motivating factors influencing the adoption of Internet banking services.

\section{MEAsurement of VARIABles}

For this study, respondents are considered as adopters if they are currently using retail internet banking to perform banking transactions. The questions were measured using five-point Likert scale and respondents are required to indicate their responses using $1=$ Strongly Disagree to $5=$ Strongly Agree. It was found that five point likert scale has become the norm in many research works probably because it strikes a compromise between the conflicting goals of offering sufficient choice as respondents find it easy and convenient to respond to the questionnaires. Research confirms that data from Likert items and those with similar rating scales becomes significantly less accurate when the number of scale points increases more than five. In addition, more than five point likert scale confuses respondents in selecting the responses [50]. [51] revealed $80 \%$ give a top rating in overall opinion survey on 5-point liker scale compared to only $62 \%$ on a 7 -point likert scale measurement.

\section{RESPOND RATE}

A total of 300 questionnaires were distributed at various banking outlets in Malaysia and managed to receive 207 responses only. Though there were many potential respondents visited the bank branches for branch banking only 300 respondents volunteered to participates in the survey given limited time. Out of 300 respondents, only 207 respondents adequately and completely answered all the questions in the survey questionnaires. Another 93 questionnaires were found to be incomplete in responses and excluded from this survey.

\section{RESULtS}

The Mann-Whitney U test is commonly used alternatively to t-test [52]. It is powerful compares the number of times a score of one of the samples ranked higher that a score from the other sample [53] irrespective of the shapes of distribution of data [52]. The two tailed probability was used to find out if any difference between adopters and non adopters perceptions and if the scores between twoi groups were statistically significant [54]. The results of the Mann-Whitney U-test as shown in table indicate that out of 6 areas assessed all are showing significant differences 
between adopters and non adopter's perceptions. The Mann-Whitney test, also called the rank sum test, is a nonparametric test that compares two unpaired groups. Mann-Whitney test ranks all the values from low to high, paying no attention to which group each value belongs. If two values are the same, then they both get the average of the two ranks for which they tie. The smallest number gets a rank of 1 . The largest number gets a rank of $\mathrm{N}$, where $\mathrm{N}$ is the total number of values in the two groups. Prism then sums the ranks in each group, and reports the two sums. If the sums of the ranks are very different, the $\mathrm{P}$ value will be small.

\section{A. Easier to Operate}

In table 2, Mann Whitney-Wilcoxon result shows the difference between adopters and non adopters. $\mathrm{U}=$ Mann-Whitney test statistic $=2255.50 ; \mathrm{W}=$ Wilcoxon $\mathrm{W}$ Statistic $=4740.50 ; \mathrm{z}=\mathrm{U}$ transformed into a normally distributed $\mathrm{z}=-6.674 ; \mathrm{p}=0.000<0.001$ levels The test statistic result indicates that there is a significant difference between adopters and non adopters of Internet banking in terms of easier to operate among Malaysian banking customers. Therefore hypothesis H1 is accepted.

TABLE II: ANALYSES ON EASIER TO OPERATE

\begin{tabular}{|l|r|}
\multicolumn{2}{c}{ Test Statistics } \\
\hline \multicolumn{1}{|c|}{ a } \\
\hline Mann-Whitney U & $\begin{array}{c}\text { Easier to } \\
\text { operate }\end{array}$ \\
Wilcoxon W & 2255.500 \\
Z & 4740.500 \\
Asymp. Sig. (2-tailed) & -6.674 \\
\hline \multicolumn{2}{|c|}{ a. Grouping Variable: Internet banking Usage }
\end{tabular}

\section{B. Convenient to Use}

In table 3, Mann Whitney-Wilcoxon result shows the difference between adopters and non adopters. $\mathrm{U}=$ Mann-Whitney test statistic $=2241.50 ; \mathrm{W}=$ Wilcoxon $\mathrm{W}$ Statistic $=4726.50 ; \mathrm{z}=\mathrm{U}$ transformed into a normally distributed $\mathrm{z}=-6.738 ; \mathrm{p}=0.000<0.001$ levels The test statistic result indicates that there is a significant difference between adopters and non adopters of Internet banking in terms of convenient to use among Malaysian banking customers. Therefore hypothesis H2 is accepted.

TABLE III: ANALYSIS ON CONVENIENT TO USE

Test Statistics a

\begin{tabular}{|l|r|}
\hline & \multicolumn{1}{|c|}{ Convenient } \\
\hline Mann-Whitney U & 2241.500 \\
Wilcoxon W & 4726.500 \\
Z & -6.738 \\
Asymp. Sig. (2-tailed) & .000 \\
\hline
\end{tabular}

a. Grouping Variable: Internet banking Usage

\section{Hassle Free}

In table 4, Mann Whitney-Wilcoxon result shows the difference between adopters and non adopters. $\mathrm{U}=$ Mann-Whitney test statistic $=3171.00 ; \mathrm{W}=$ Wilcoxon $\mathrm{W}$ Statistic $=5656.00 ; \mathrm{z}=\mathrm{U}$ transformed into a normally distributed $\mathrm{z}=-4.219 ; \mathrm{p}=0.000<0.001$ levels The test statistic result indicates that there is a significant difference between adopters and non adopters of Internet banking in terms of hassle free to use among Malaysian banking customers. Therefore hypothesis H3 is accepted.

TABLE IV: ANALYSES ON HASSLE FREE

\begin{tabular}{|l|r|}
\multicolumn{2}{|c|}{ Test Statistics } \\
\hline \multicolumn{2}{|c|}{ a } \\
\hline Mann-Whitney U & No hassle \\
Wilcoxon W & 3171.000 \\
Z & 5656.000 \\
Asymp. Sig. (2-tailed) & -4.219 \\
\hline
\end{tabular}

a. Grouping Variable: Internet banking Usage

\section{Reliable}

In table 5, Mann Whitney-Wilcoxon result shows the difference between adopters and non adopters. $\mathrm{U}=$ Mann-Whitney test statistic $=2493.00 ; \mathrm{W}=$ Wilcoxon $\mathrm{W}$ Statistic $=4978.00 ; \mathrm{z}=\mathrm{U}$ transformed into a normally distributed $\mathrm{z}=-6.059 ; \mathrm{p}=0.000<0.001$ levels The test statistic result indicates that there is a significant difference between adopters and non adopters of Internet banking in terms of reliable among Malaysian banking customers. Therefore hypothesis H4 is accepted.

TABLE V: ANALYSIS ON RELIABLE

\begin{tabular}{|l|r|}
\multicolumn{2}{c}{ Test Statistics } \\
\hline \multicolumn{1}{|c|}{ a } \\
\hline Mann-Whitney U & Reliable \\
Wilcoxon W & 2493.000 \\
Z & 4978.000 \\
Asymp. Sig. (2-tailed) & -6.059 \\
\hline
\end{tabular}

a. Grouping Variable: Internet banking Usage

\section{E. Safer to use}

In table 6, Mann Whitney-Wilcoxon result shows the difference between adopters and non adopters. $U=$ Mann-Whitney test statistic $=3347.50 ; \mathrm{W}=$ Wilcoxon $\mathrm{W}$ Statistic $=5832.50 ; \mathrm{z}=\mathrm{U}$ transformed into a normally distributed $\mathrm{z}=-3.707 ; \mathrm{p}=0.000<0.001$ levels The test statistic result indicates that there is a significant difference between adopters and non adopters of Internet banking in terms of safer to use among Malaysian banking customers. Therefore hypothesis H5 is accepted.

TABLE VI: ANALYSIS ON SAFER TO USE

\begin{tabular}{|l|r|}
\multicolumn{2}{|c|}{ Test Statistics } \\
\hline \multicolumn{2}{|c|}{ a } \\
\hline Mann-Whitney U & Safe to use \\
Wilcoxon W & 3347.500 \\
Z & 5832.500 \\
Asymp. Sig. (2-tailed) & -3.707 \\
a. Grouping Variable: Internet banking Usage \\
\hline \multicolumn{2}{|c|}{}
\end{tabular}

\section{F. Requirement for Good Internet Connections}

In table 7, Mann Whitney-Wilcoxon result shows the difference between adopters and non adopters. $\mathrm{U}=$ Mann-Whitney test statistic $=2924.50 ; \mathrm{W}=$ Wilcoxon $\mathrm{W}$ Statistic $=5409.50 ; \mathrm{z}=\mathrm{U}$ transformed into a normally distributed $\mathrm{z}=-4.909 ; \mathrm{p}=0.000<0.001$ levels The test 
statistic result indicates that there is a significant difference between adopters and non adopters of Internet banking in terms of requirement for good Internet connections among Malaysian banking customers. Therefore hypothesis H6 is accepted.

TABLE VII: ANALYSES ON REQUIREMENT FOR GOOD INTERNET CONNECTIONS

\begin{tabular}{|l|r|}
\multicolumn{2}{|c|}{ Test Statistics a } \\
\hline \multicolumn{1}{|c|}{$\begin{array}{c}\text { Connections } \\
\text { are good }\end{array}$} \\
\hline Mann-Whitney U & 2924.500 \\
Wilcoxon W & 5409.500 \\
Z & -4.909 \\
Asymp. Sig. (2-tailed) & .000 \\
\hline \multicolumn{2}{|c|}{ a. Grouping Variable: Internet banking Usage }
\end{tabular}

\section{RESULTS}

This study investigates the perceptual differences between adopters and non adopters among Malaysian banking customers in adopting Internet banking services. The results indicate that all hypotheses regarding easier to operate, convenient, hassle free, reliable, safer to use and requirement for good Internet connections were supported. Therefore it is confirmed that the factors of adoption analyzed in this study shows significant differences in perception between adopters and non adopters.

This study supports the findings of previous research by [30, 29, 26, 27, 25 and 55] on the significant difference in perception between adopters and non adopters in terms of easier to operate. Non adopters perceive Internet banking as difficult to operate and therefore they are reluctant to switch from traditional banking to Internet banking and hence the probability to adopt Internet banking is low. Bank Managers should promote Internet banking through trainings, workshops, dialogues to convince non adopters to adopt Internet banking.

This research suggests the findings of previous research by $[2,19,31,56,57$, and 58] on the significant difference in perception between adopters and non adopters in terms of convenient to use. Non adopters perceive Internet banking as inconvenient and therefore they are unwilling to change from branch banking to Internet banking and hence the likelihood to adopt Internet banking is low. Bank Management should encourage non Internet banking adopters through trainings, workshops, dialogues to convince to adopt Internet banking.

This research suggests the findings of previous research by [5, 32, 33, 34, 35 and 36] on the significant difference in perception between adopters and non adopters in terms of Hassle Free. Non adopters perceive Internet banking as hassle and therefore they are unwilling to change from brick and mortar banking to Internet banking and hence the likelihood to adopt Internet banking is low. Banks should encourage non Internet banking adopters through trainings, workshops, dialogues to convince to adopt Internet banking.

This research suggests the findings of previous research by $[10,12,39,37,38$ and 40] on the significant difference in perception between adopters and non adopters in terms of Reliable. Non adopters perceive Internet banking as no reliable and therefore they are unwilling to change from branch banking to Internet banking and hence the likelihood to adopt Internet banking is low. Banks should encourage non Internet banking adopters through trainings, workshops, dialogues to convince to adopt Internet banking.

This research suggests the findings of previous research by [12, 25, 42, 43 and 59] on the significant difference in perception between adopters and non adopters in terms of Safer to use Non adopters perceive Internet banking as unsafe and therefore they are unwilling to change from traditional banking to Internet banking and hence the likelihood to adopt Internet banking is low. Banks should encourage non Internet banking adopters through trainings, workshops, dialogues to convince to adopt Internet banking.

This research suggests the findings of previous research by $[17,38,46,47,48,49$ and 60$]$ on the significant difference in perception between adopters and non adopters in terms of requirement for good Internet connections. Non adopters perceive that Internet Connections are weak for adopting Internet banking services and therefore they are unwilling to change from branch banking to Internet banking and hence the likelihood to adopt Internet banking is low. Banks should encourage non Internet banking adopters through trainings, workshops, dialogues to convince to adopt Internet banking.

It is important to have campaigns to promote internet banking usage. Guidance on how to use internet banking should also be provided on the web and at physical distribution centre to facilitate the consumers. In addition, assuring the security of the internet transactions to consumers might positively affect consumers' attitude towards adoption and use of Internet banking.

\section{SugGeStion FOR Future RESEARCH}

Bank marketing researchers will need to focus on customer's needs, attitudes, values and behaviours in the adoption of Internet banking. It will help in understanding and anticipating customer needs that can be incorporated in product development and banking services differentiation. Research in monitoring of customer satisfaction with personal service and with automated service-delivery methods need to be improved in order to pinpoint areas where service quality can be enhanced. Study in Internal marketing and usage of technology in banking services need to be explored further to profile the customer segment that will enhance customer loyalty and customer relationship.

\section{CONCLUSION}

This study aims to identify the perceptual differences between Internet Banking Adopters and Non-adopters especially in the Malaysian Retail Banking Sector. It investigates whether the adoption factors such as easier to operate, convenient, hassle free, reliable, safer to use and requirement for good Internet connections varies between adopters and non-adopters. This study adopts a quantitative approach using questionnaire survey at selected banks in Malaysia. The results indicate that there are significant differences between internet banking adopters and non-adopters in terms of easier to operate, convenient, no 
hassle, reliable, safer to use and good Internet connections. Thus, the result suggests managerial implications for retail bankers in Malaysia to encourage non adopters to change from traditional banking to internet banking. As more traditional banking customers shift to Internet banking, banks will experience lower cost of operations as paperless administration increases in various bank branches.

\section{REFERENCES}

[1] M. S Sohail and B. Shanmugham, "E-banking and customer preferences in Malaysia: An empirical investigation," Information Sciences, vol 150, no 4, pp 207-217, 2003.

[2] E. Turban, J. Lee, D. King, and H. Chung, Electronic Commerce: A Managerial Perspective. Pretence Hall International Inc.2000.

[3] G. Philip and J. B. Cunningham, "The diffusion of internet banking among Singapore consumers,” International Journal of Bank Marketing, vol. 21, No. 1, pp. 16-28. 2003.

[4] E. M. Rogers, "Diffusion of innovations," New York: Free Press, pp.15-17.1995.

[5] M. Tan and T. S. H. Teo, "Factors influencing the adoption of internet banking", Journal of the Association for Information Systems, vol. 1, no.5, pp. 1-44. 2000.

[6] S. Kurnia, F. Peng, and Y. R. Liu, "Understanding the adoption of electronic banking in China," In Proceedings of HICSS. pp. 1-10, 2010.

[7] B. M. Kim, R. Widdows, and T. Yilmazer, "The determinants of consumer adoption of internet banking," (Unpublished Doctoral dissertation, Purdue University, 2001).

[8] Household Use of the Internet Survey. - HUIS, [Online]. Available: http://www.enzi nearticles. Assessed on 25th May 2011.

[9] AcNielsen. (2007) Seek and You Shall Buy. Entertainment and Travel. [Online]. Available: http://www2.acnielsen.com/news/20051019.shtml, Assessed on 12th July 2011.

[10] ABA, (2004) Affluent Customers Going Online. ABA eAlert, IV (10), May 14, ABA Bankers News, American Bankers Association. [Online] Available: http://www.aba.com/Ind ustry+Issues/ealert410.htm.

[11] S. Fox. (2005). Online Banking Jumps 47\% in 2 Years. Pew Internet and American Life Project. [Online]. Available: http://www.pewInternet.org/pdfs/PIP_Online_Banking_2005.pdf.

[12] M. Rod, N. J Ashill, J. Shao, and J. Carruthers, "An examination of the relationship between service quality dimensions, overall internet banking service quality and customer satisfaction: A New Zealand study,” Marketing Intelligence and Planning, vol. 27, No. 1, pp. 103-126. 2009.

[13] S. G. Krauter and R. Faullant, "Consumer acceptance of internet banking: the influence of internet trust," International Journal of Bank Marketing, vol. 26, No. 7, pp. 483-504, 2008.

[14] B. Orr, "E-banking job one: Give customers a good ride," ABA Banking Journal, vol. 96, no. 5, pp. 40-49, 2004.

[15] B. Orr, "Where will internet banking be in two years?" ABA Banking Journal, vol. 87, no 3, pp. 56-61. 1998.

[16] M. Mattila, H. Karjaluoto, and T. Pento, "Internet banking adoption among mature customers: Early majority or laggards”, Journal of Services Marketing, vol 17, pp. 514 - 528, 2003.

[17] L. Bradley and K. Stewart, "Delphi study of internet banking," Marketing Intelligence and Planning, vol. 21, no.5, pp. 272-281.2003.

[18] B. Jaruwachirathanakul and D. Fink, "Internet banking adoption strategies for a developing country: The case of Thailand," Internet Research, 15(3), 295-311.2005.

[19] S. S. Alam, A. Khatibi, A. S. Santhapparaj, and M. Talha, "Development and prospects of internet banking in Bangladesh," Competitiveness Review, vol. 17, no. 1/2, pp. 56-66.

[20] M. C. Lee, "Factors influencing the adoption of internet banking: An integration of TAM and TPB with perceived risk and perceived benefit," Electronic Commerce Research and Applications, vol. 8, no. 3, pp. 130-141, 2009.

[21] J. A. Manzano, "The role of consumer innovativeness and perceived risk in online banking usage," International Journal of Bank Marketing, vol. 27, no. 1, pp, 53-75, 2009.

[22] S. Liao, Y. P. Shao, H. Wang, and A. Chen, "The adoption of virtual banking: An empirical study," International Journal of Information Management, vol. 19, no. 1, pp. 63-74, 1999.

[23] N. P. Mols, "The Internet and Services marketing - The case of Danish retail banking," Internet Research Electronic Networking Applications and Policy, vol. 10, no. 1, pp. 7-18, 2000.
[24] A. M. Sakkthivel, "Impact of demographic on the consumption of different services online in India," Journal of Internet Banking and Commerce, vol. 11, no. 3, 2006.

[25] T. Ramayah, F. M. Taib, and K. P. Ling, "Classifying users and non-users of internet banking in northern Malaysia," Journal of Internet Banking and Commerce, vol. 11, no. 2, 2006.

[26] P. Gao and O. Owolabi, "Consumer adoption of internet banking in Nigeria,” Int. J.Electronic Finance, vol. 2, no. 3, pp.284-299, 2008.

[27] N. P. Mols, "The internet and services marketing - The case of Danish retail banking," Internet Research Electronic Networking Applications and Policy, vol. 10, no. 1, pp. 7-18, 2000.

[28] M. Sathye "Adoption of internet banking by Australian consumers: an empirical investigation," International Journal of Bank Marketing, vol. 17, no. 7, pp. 324-334, 1999.

[29] L. R. Flynn and R. E. Goldsmith, "Application of the personal involvement inventory in marketing," Journal of Psychology and Marketing, vol. 10, pp. 357-366, 1993.

[30] F. D. Davis, R. P. Bagozzi, and P. R. Warshaw, "User acceptance of computer technology: A comparison of two theoretical models," Management Science, vol. 35, no. 8, pp.982-100, 1989.

[31] O. H. Boon and C. M. Yu, "Success factors in e-channels: the Malaysian banking scenario," International Journal of Bank Marketing, vol. 21, no. 6, pp. 369-377, 2003.

[32] E. M Auta, "E-banking in developing economy: Empirical evidence from Nigeria," Journal of Applied Quantitative Methods, vol. 5, no.2, 2010.

[33] Y. Y. Shih, (2007). The study of customer attitude towards Internet banking based on the Theory of Planned Behavior. [Online]. Available: http://ibacnet.org/bai2007/proceedings/Papers/2007bai7536.pdf

[34] D Singhal and V. Padhmanabhan, "A study on customer perception towards internet banking: Identifying major contributing factors," The Journal of Nepalese Business Studies, vol. 5, no.1, 2008.

[35] S. Divya and V. A Padhmanabhan, "Study on customer perception towards internet banking: Identifying major contributing factors," The Journal of Nepalese Business Studies, vol. 5. no. 1, December 2008, pp 101-111.

[36] S. Mahdi and A. Mehrdad, "E-Banking in emerging economy: empirical evidence of Iran," International Journal of Economics and Finance, vol. 2, no. 1, February 2010, pp. 201-209.

[37] W. M. Lassar, C. Manolis, and S. S. Lassar, "The relationship between consumer innovativeness, personal characteristics, and online banking adoption,” International Journal of Bank Marketing, vol. 23, no. 2, pp. 176-199. 2005.

[38] S. Rotchanakitumnuai and M. Speece, "Barriers to internet banking adoption: A qualitative study among corporate customers in Thailand," International Journal of Bank Marketing, vol. 21, no. 6, pp. 312-323, 2003.

[39] M. Jun and S. Cai, "The key determinants of internet banking service quality: A content analysis," International Journal of Bank Marketing, vol. 19, no. 7, pp. 276-91, 2001.

[40] C. Jayawardhena, "Measurement of service quality in internet banking: the development of an instrument," Journal of Marketing Management, 20 (1/2),185-207, 2004.

[41] S. Laforet and X. Li, "Consumers' attitudes towards online and mobile banking in China", International Journal of Bank Marketing, vol. 23, no. 5, pp. 362-380, 2005

[42] S. McKechnie, H. Winklhofer, and C. Ennew, "Applying the technology acceptance model to the online retailing of financial services," International Journal of Retail and Distribution Management, vol. 34, no. 4/5, pp. 388-410, 2006.

[43] C. Flavian and M. Guinaliu, "Consumer trust, perceived security and privacy policy: Three basic elements of loyalty to a web site," Industrial Management and Data Systems, 106(5), 601-620, 2006.

[44] D. Hutchinson and M. Warren, "Security for internet banking: a framework," Logistics Information Management, vol. 16, no. 1, pp. 64-73, 2003.

[45] K. Eriksson, K. Kerem, and D. Nilsson, "Customer acceptance of internet banking in Estonia," International Journal of Bank Marketing, vol. 23 Iss: 2, pp. $200-216,2005$.

[46] S. Li and A. C. Worthington, (2004) 'The relationship between the adoption of Internet banking and electronic connectivity: - An international comparison', Discussion paper, School of Economics and Finance, Queensland University of Technology, Brisbane QLD, Australia.

[47] V. Perumal and Shanmugan, 'Internet banking: Boone or Bane," Journal of Internet Banking and Commerce, vol. 19, no. 3, 2004. 
[48] D. Thulani, C. Tofara, and R. Langton, "Adoption and use of internet banking in Zimbabwe: An exploratory study," Journal of Internet Banking and Commerce, vol. 14, no.1, 2009.

[49] DB Research, Forrester Research Inc., (2006). Retail banking via internet banking online boosts and curbs customer loyalty. [Online]. Available: http://www.dbresearch.com/PROD/ DBR_INTERNET_EN-PROD/PROD0000000000203929.PDF

[50] R. Johns. (2010). Likert items and scales, survey question bank: Methods fact sheet $1 . \quad$ [Online]. Available: http://www.surveynet.ac.uk/sqb/datacollection/likertfactsheet.pdf

[51] M. Conklin. (2006) Measuring and tracking customer satisfaction. [Online]. http://www.zoomerang.com/whitepapers/customersat.pdf

[52] A. Bryman and D. Cramer, Quantitative Data Analysis with SPSS for windows. New York: Routledge, 1997.

[53] M. J. Norusis, (1999) SPSS 9.0, Guide to data analysis, New Jersey, USA: Prentice Hall

[54] A. Yuksel, "Shopping experience evaluation, a case of domestic and international visitors," Tourism Management, 25, 751-759, 2003.

[55] M. Sathye, "Adoption of Internet banking by Australian consumers: An empirical investigation," International Journal of Bank Marketing, vol. 17, no. 7, pp. 324-334, 1999.

[56] M. Jun, Z. Yang, and D. Kim, "Customers' perceptions of online retailing service quality and their satisfaction," International Journal of Quality and Reliability Management, vol. 21 no. 8, pp. 817-40, 2004.

[57] N. P. Mols, "The internet and services marketing - The case of Danish retail banking," Internet Research Electronic Networking Applications and Policy, vol. 10, no. 1, pp. 7-18, 2000.

[58] L. A Pham, "Conceptual framework for e-banking service quality in Vietnam," Proceedings of 2nd Annual General Business Conference, Sam Houston State University, Huntsville, 2010.

[59] S. Liao, Y. P. Shao, H. Wang, and A. Chen, "The Adoption of virtual banking: An empirical study," International Journal of Information Management, vol. 19, no. 1, pp. 63-74, 1999.

[60] S. A Al-Somali, R. Gholami, and B. Clegg. (2008) Internet Banking Acceptance in the Context ofDeveloping Countries: An Extension of the Technology Acceptance Model. [Online]. Available: http://webintec.ceram.fr/euromot2008/conftool/uploads/388/1-Internet _banking-Final_copy.pdf.

[61] "Corporate customers in Thailand.” International Journal of Bank Marketing, vol. 21, no. 6, pp. 312-323.

[62] A. M. Sakkthivel, "Impact of demographic on the consumption of different services online in India," Journal of Internet Banking and Commerce, vol. 11, no. 3, 2006.

[63] M. Sathye, "Adoption of Internet banking by Australian consumers: An empirical investigation," International Journal of Bank Marketing, vol. 17, no. 7, pp. 324-334, 1999

[64] Y. Y. Shih. (2007). The study of customer attitude towards Internet banking based on the Theory of Planned Behavior. [Online]. Available: http://ibacnet.org/bai2007/proceedings/Papers/2007bai7536.pdf

[65] D. Singhal and V. Padhmanabhan, "A study on customer perception towards internet banking: Identifying major contributing factors," The Journal of Nepalese Business Studies, vol. V, no.1, 2008.
[66] M. S. Sohail and B. Shanmugham, "E-banking and customer preferences in Malaysia: An empirical investigation," Information Sciences, vol 150, no 4, pp 207-217, 2003.

[67] R. Suganthi, K. G. Balachandher, and Balachandran, "Internet banking patronage: An empirical investigation of Malaysia,” Journal of Internet Banking and Commerce, vol. 6, no. 1. [Online]. Available: http://www.arraydev.com/commerce/JIBC/0103_01.htm, 2001.

[68] M. Tan and T. S. H. Teo, "Factors influencing the adoption of internet banking," Journal of the Association for Information Systems, vol. 1, no.5, pp. 1-44, 2000.

[69] D. Thulani, C. Tofara, and R. Langton, "Adoption and use of internet banking in Zimbabwe: An exploratory study," Journal of Internet Banking and Commerce, vol. 14, no.1, 2009.

[70] E. Turban, J. Lee, D. King, and H. Chung, 2000. Electronic Commerce: A Managerial Perspective. Pretence Hall International Inc.

[71] A. Wirekoon. (2010). Online banking. [Online]. Available: http://www.docstoc.com/docs/2254 3071/Online-banking.

[72] A. Yuksel, "Shopping experience evaluation, a case of domestic and international visitors," Tourism Management, vol. 25, pp. 751-759, 2003.

[73] C. Jayawardhena, "Measurement of service quality in internet banking: The development of an instrument," Journal of Marketing Management, vol. 20, no. 1/2,185-207, 2004.

[74] C. Flavian and M.Guinaliu, "Consumer trust, perceived security and privacy policy: Three basicelements of loyalty to a web site," Industrial Management and Data Systems, vol. 106, no. 5, 601-62, 2006.

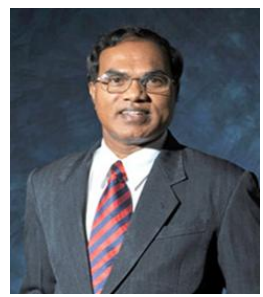

Dr. Jayaraman Munusamy is currently attached to Masterskill University College Education Group as a Professor cum Deputy Dean of Faculty of Business \& Law. Previously, Dr. Jayaraman Munusamy served Limkokwing University of Creative Technology as an Associate Professor in the Centre of Post-Graduate Studies. Prior to that, he had served University Tun Abdul Razak as an Assistant Professor in the Faculty of Business Administration. He started his career as a trained teacher in 70's and moved on to the private sector working with a Malaysian Company as a Marketing Manager for 6 years in the area of Consumer Product Marketing in 80 's.

During 90's, he served as an Industrial Marketing Manager for Ikeda Bussan in its Malaysian operation for 10 years. He has also served Johnson Controls Automotive Holdings in its Malaysian plant and later on to take charge of leadership in Six Sigma implementation in Johnson Controls Plants located in the Asia-Pacific Region between 2000 and 2006. He has a vast experience in Marketing, Teaching, Training and Consultancy which he had acquired from American, Japanese and Malaysian Multinational Companies. He has a Bachelor Degree in Business Management, Masters in Business Administration and Doctorate in Business Administration. He is also a Certified Black Belt in Six Sigma Methodologies which was awarded by Johnson Controls Incorporation, USA. 